would not have been countenanced twenty years ago. The birth of antiseptic surgery set the medical scientist thinking, and thus our latest addition " bacteriology" came into being. Finally, we have plenty of proof of the progression of the sanitarian in our colonies and elsewhere; we only want to spur those of our neighbours who are behindhand. As the bacteriologist advances and new antitoxin remedies are produced, perhaps in a few decades that most insidious, variable, and vicious parasite the bacillus malariæ will be conquered and cease to bring upon us so much pain and sorrow as it has done recently.

I am, Sirs, your obedient servant,

Alton, Hants, Feb. 8th, 1896.

J. F. Briscow.

\section{A POINT UNDER THE INFECTIOUS DISEASES (NOTIFICATION) ACT.}

\section{To the Editors of THE LANCET.}

SIRS,--May I ask you to insert the enclosed copy of a Setter from the Local Government Board. The town clerk of Peterborough informed me that my conduct in reporting every case of infectious disease was " not justifiable," but that I should only report one in a house. Considering this opinion to be incorrect I wrote to the Local Government Board. The answer fully supports my opinion.

I am, Sirs, yours truly,

The Mansion House, Peterborough. Leonard Cane, M.D. [COPY.]

"Local Government Board, Whitehall, S.W., Feb. 11th, 1896. "SIR,-I am directed by the Local Government Board to advert to grour letter of the 30th ultimo, and, in reply, I am to state that, as the Board are advised, a medical practitioner is required by the Infectious Disease (Notification) Act, 1889, to give notice to tbe medical officer of health of the district respecting every patient suffering from an infections disease within the meaning of the Act whom he may attend or be called in to visit (unless such patient is an inmate of a hospital in which persons suffering from an infectious disease are received), and that the town council must pay the prescribed fee for each certificate, wihether or not it relates to a person belonging to a family in which the presence of infectious disease has already been notified.

"I am, Sir, your obedient servant,

"C. W. CALTON, Assistant' Secretary.

"L. Cane, Esq., M.D., the Mansion House, Peterborough."

** It is clear that any other interpretation of the Act would be impossible and lead to endless confusion.-ED. $L$.

\section{"UNQUALIFIED ASSISTANTS AND THEIR PRINCIPALS."}

To the Editors of THE LANCET.

SIRS,-Having read your interesting article on the employment of unqualified assistants I may be allowed to point out that the directions issued by the General Medical Council on the subject are admittedly too vague and indecipherable to be of any practical application. I venture, however, to bring before your notice one point on which the Council might be asked to place its veto in no indefinite terms, and that is with regard to discountenancing the system, which is by no means extinct, of locating unqualified men in branch surgeries, because it is, or should be, obvious to any that under these circumstances such unqualified practitioners are to all intents and purposes performing the medical functions of registered practitioners. Quite recently a case has come to my notice by accident in which an unregistered practitioner, under conditions which I have described, having seen a child which died, his principal, being unable to grant a certificate, represented to the coroner "dentition" as the probable cause of deathcertainly a rather skilful diagnosis for one who had not seen the child alive. Now let us suppose that an inquest had been duly held in this case and that the coroner had forwarded his notes to the Council with a view of their taking cognisance of this illicit kind of practice, of what earthly use could such evidence be to the Council, seeing that it could only be evidence of that which is already selfevident-viz., that practice is conducted in these branch surgeries, as I have before observed, to all intents and purposes as though qualified men resided on the premises; and that the only practical distinction between " covering" in this sense and "covering" as applied to protecting a quack who practises on his own account consists in the difference that in the latter case the unqualified man directly pockets the cash, whereas in the former he puts it into the pocket of his principal? Under these considerations I would suggest that the Council might hold the practice I have described, after due notice, as "infamous conduct in a professional sense," and such a decree would operate with justice towards the public, with justice towards well-disposed registered practitioners, and with no undue harshness towards the unqualified assistant.-I am, Sirs, yours truly,

Queen's-road, S.E., Feb. 2nd, 1896 . CLEMENT H. SERs.

** As a matter of fact the General Medical Cuuncil does take the view of an unqualified assistant in charge of a branch practice held by our correspondent and has often been guided by it in actual cases. Perhaps our correspondent's letter may induce the Council to be more explicit in its condemnation of such a system, but such a use of an unqualified assistant is certainly improper and would render a practitioner liable to a charge of covering.-ED. L.

\section{To the Editors of THE LANCET.}

SIRs,-Referring to the inquest held by Mr. Wyatt on the body of Alice Emily Hall, upon which you comment in THE LANCET of Feb. 8th I have to say your remarks receive my entire adhesion. I have always been to the fore in the ranks of those of our profession who rigidly oppose the abuse of the use of unqualified assistants. But in this case the action of my assistant, an advanced hospital student who has passed in surgery, \&c., and who is now actively reading for the medicine and midwifery final, has my entire approval. I not only endorse his action in the matter, but I desire to state emphatically that I should have been extremely annoyed and hurt had he so far forgotten his manifest duty as to have refused. to accompany the weeping mother home for the purpose of rendering immediate aid and satisfaction to her in her distress. At a time of trouble and in extreme emergency I hold that the best help available at the moment must be obtained and given. In the present instance the mother alleged she had been to several medical men, only to find them out-it was midday. She was told that I was out also. "Oh, cannot you come and tell me whether my baby is dead or no?" "Yes, I can, and I will, and the doctor shall follow on." Really, Sirs, need I say anything more?

Stockwell-road, S.W., Feb. 9th, 1896.

I am, Sirs, yours faithfully, JoHN P. HENTsch.

\section{A MISCHIEVOUS IMPERSONATION.}

\section{To the Editors of THE LANCET.}

SIRs,--It has just come to my knowledge that a certain person, who will shortly be charged with the offence, has been writing to two medical friends of mine begging for money. He signs himself by name and represents that I am in monetary difficulties and about to resign my practice at Ladbroke-grove, which, of course, has no foundation in fact. As probably he has written to many others besides the two I have knowledge of, will you kindly insert this in your paper? I am, Sirs, yours faithfully, 76, Ladbroke-grove, W., Feb. 10th, 1896 . G. L. TURnBULL.

\section{"EXAMINERS AND EXAMINEES."}

\section{To the Editors of THE LANCET.}

SIRs,--May I trespass on your valuable space for insertion of the following facts, which I have no doubt will be of as much interest to examiners and candidates alike as they were of painful experience for me? At the recent (January) final examination of the Conjoint Board for the diploma of M.R.C.S. and L.R.C.P. I was a candidate. At the vivâa-voce in medicine I took my seat opposite a certain examiner (whose name I shall not mention here) who by his manners caused me to become considerably perturbed and nervous, and, as the following will show, brought me within an ace of losing my temper and as a certain sequence my chances of success in examination. Now, some candidates have had the bitter experience, from time to time, of being bullied $\mathrm{ky}$ examiners, but few, I am glad to say, have had the unique privilege of being grossly and unreasonably 